\title{
Liberia: \\ Understanding Alternative Dispute Resolution Mechanisms in Post-Conflict Societies
}

\author{
Olugbemiga Samuel AFOLABI \\ Harrison Adewale IDOWU \\ George Tee FORPOH
}

\begin{abstract}
Olugbemiga Samuel AFOLABI
Department of Politics and International Relations, University of Johannesburg South Africa

Department of Political Science, Obafemi Awolowo University, lle-lfe, Nigeria

E-mail: oafolabi@uj.az.za; osafolabi@oauife.edu.ng

Harrison Adewale IDOWU

Department of Political Science, Obafemi Awolowo University, lle-Ife, Nigeria E-mail:
\end{abstract}

Abstract: Conflict and its resolution have often been part of human history. While the post-colonial state has often been the focus when explaining the persistence of conflicts and its resolution in Africa, the benefits of such focus and analysis has not been enough to explain the intra-and

\section{George Tee FORPOH}

Makerere University, Uganda

M \& E Consultant, Liberia

E-mail: forpohtee@yahoo.com

Conflict Studies Quarterly

Issue 26, January 2019, pp. 3-21

DOI:10.24193/csq.26.1

Published First Online: 05/01/2019 inter-state nature of conflicts and conflict management in Africa. This necessitates a reconsideration of conflict management strategies. Such reconsideration will show the intricate ways conflicts and its resolutions are shaped, especially in post-conflict societies, through the instrumentality of Alternative Dispute Resolution (ADR) mechanism. With Liberia as the focus and unit of analysis, it noted that the country has been the epicentre of several years of violent conflicts with both internal and external dimensions, raising questions about the effectiveness of the orthodox conflict management mechanisms given that the Liberian conflict was intractable for a long time. However, the adoption of alternative dispute resolution mechanisms has helped resolve most, if not all, of the conflicts. This paper, therefore, examines the local, traditional and communal alternative dispute resolution mechanisms used to solve the Liberian crisis. Specifically, the paper interrogates traditional methods of conflict resolution, inclusive of communalism, ethnocultural perception of conflicts and its resolution, as 
well as epistemic and ethical protocols guiding peace-building efforts. This is with the aim to provide an understanding of Africa's peace initiatives, choices and options.

Keywords: ADR, Post-conflict Societies, Liberia, Africa.

\section{Introduction}

Conflicts are part of human relations; as individuals and groups have orientations and beliefs that are often contradictory, resulting in disputes. These differences also play out in how conflicts and disputes are resolved. However, in post-colonial state Africa, the state focus, given its origin as a colonial creation and its character that is steeped in violence, has always been fixed on the state when explaining the persistence of conflicts and its resolution in Africa. While this has some benefits, it is not enough to explain the intra-and inter-state nature of conflicts and its difficulties in Africa. The urgent need for a reconsideration of conflict management strategies in Africa, that shows the intricate ways conflicts and its resolutions are shaped, especially in post-conflict societies through the instrumentality of Alternative Dispute Resolution (ADR) mechanism, becomes germane. The large number of African countries that have experienced and are still experiencing violent conflicts are steadily reducing (Bakken \& Rustad, 2018; ACLED, 2017; Afolabi, 2015). However, Liberia, as the epicentre of violent conflicts for years, presents the unique opportunity to examine the causes of violence and the methods used to achieve peace in the country. Liberia is also very useful as the unit of analysis because it witnessed several years of violent conflicts with both internal and external dimensions - a conflict that was intractable for a long time, raising questions about the effectiveness of the orthodox conflict management mechanisms. The orthodox conflict management mechanism had to do with the court system, of characterised by and resulting in series of unending litigations. The adoption of alternative dispute resolution mechanisms has helped to largely resolve the conflicts. This paper, therefore, examines the local, traditional and communal alternative dispute resolution mechanisms used to solve the Liberian crisis. Specifically, the paper interrogates traditional methods of conflict resolution, inclusive of communalism, ethnocultural perception of conflicts and its resolution, as well as epistemic and ethical protocols guiding peace-building efforts. This is with the aim to provide an understanding of Africa's peace initiatives, choices and options.

The paper is structured as follows. The first section opens with the introduction, followed by conceptualization of what conflicts and Alternative Dispute Resolution (ARD) means. The third section of the paper examines post-conflict societies in transition, especially Liberia, as the focus of our work. Next, the paper critically examined ADR Techniques in Liberia, detailing the various techniques used, which is followed by appraising the problems of ADR in Liberia through an examining of the techniques and lessons learned from its implementation. The next section assesses the ADR Mechanism 
as a Peace-building technique, exploring its possibilities. The last section concludes by examining what needs to be done to make ARD better in conflict resolution in Africa.

\section{Conceptualising Conflicts and Alternative Dispute Resolution (ARD)}

Conflict, in its simplest form of conceptualization, could be referred to as any situation of misunderstanding between two or more parties, usually as a result of disagreements over certain sensitive issues. Conflict, like most other terms, has received myriad of definitions. Conflict is inevitable in any human society; in as much as the interests of individuals in such society differs, there is bound to be conflict. The term has been mostly defined as a "disagreement through which the parties involved perceive a threat to their needs, interests or concerns" (Jack, 2014, p. 33; Fisher, Abdi, Smith, Williams \& Williams 2000; Pia \& Diez, 2007, p. 2; Oni-Ojo \& Roland-Otaru, 2013, p. 40). It is a situation where two or more parties desire goals which are not likely to be obtained by all parties involved, thus, leads to some sort of negative competition (Stagner, 1967). What this implies is that conflict occurs when there is a struggle over scarce resources by two or more parties. Thus, Jack (2014) posits that conflict is characterized by disagreements resulting from the distribution of scarce resources, such as mineral resources, political power, etc., which are very important to all parties involved. Conflict may also arise as a result of different/opposing cultural, religious beliefs or values which are products of opposing ways/methods of doing things or achieving a particular objective. Hence, conflict could arise from social, political and economic issues in the society.

For Diez, Stetter \& Albert (2006), "conflict denotes the incompatibility of subject positions" (p. 565). These definitions of conflict put incompatibility of interests, opinions or beliefs at the forefront of every conflict. Conflict is pervasive and occurs at various levels of society, inter-personal, family, tribes, national and international levels (OniOjo \& Roland-Otaru, 2013). Conflict has also been seen as a process which begins the moment party A perceives that party B is trying to frustrate or has already succeeded in frustrating some of his/her concerns or interest (Thomas, 1976). This implies that conflict will inevitably arise when a party's interest is at stake in the society. For Donohue and Kolt (1992) and Quincy (1971), conflict is a situation wherein interdependent groups (ethnic, tribal, religious) or persons express disagreements in a bid to achieve their diverse needs and protect their personal interests. Conflict is a dynamic process, ensuing through myriad of stages, usually from people/parties' perception that their interests are in danger of being negatively affected or already affected. Conflict can arise from issues such as failure in communication, misunderstanding, personality clashes, opposing goals and values, lack of cooperation, struggle over limited resources, among others (Oni-Ojo \& Roland-Otaru, 2013).

Dokubo and Oluwadare (2011) described conflict as a situation which can be explained in two senses. One, it refers to a situation of incompatibility between/among parties; sec- 
ondly, it refers to a situation of violent expression of this incompatibility. Furthermore, Wertheim (n.d., p. 2-3) highlights some major causes of conflict as follows:

- competition over scarce resources, time;

- ambiguity over responsibility and authority;

- opposing perceptions, work styles, beliefs, etc.;

- increase in level of interdependence, owing to more closely knitted relationship among individuals/groups;

- imbalance reward system;

- opposing points of view and goals imposed by division of labour; and

- the contentious nature and argument over equity and equality.

Conflict has been observed not to only resort in negative outcomes, as it has the potentials to also create positive outcomes (see for instance, Engel \& Korf, 2005; Pia \& Diez, 2007, p.2; Wertheim, n.d.). The table below presents some potential positive and negative outcomes of conflict.

Table 1: Potential Positive and Negative Outcomes of Conflict

\begin{tabular}{cll}
\hline S/N & \multicolumn{1}{c}{ Potential Positive Outcomes } & \multicolumn{1}{c}{ Potential Negative Outcomes } \\
\hline 1. & It can increase commitment & It can lead to anger, frustration, fear of failure, etc. \\
2. & It can give more clarity about the problem & It ensures that critical information is withheld \\
3. & It can give rise to new approaches and innovations & It lowers productivity \\
4. & It can facilitate change & It can side track career and ruin relationship \\
5. & It could sharpen approach to bargaining & It can disrupt the pattern of work \\
6. & It can lead to a solution & It leads to resource wastage, including time. \\
\hline
\end{tabular}

Source: Adapted from Wertheim (n. d., p.2)

Furthermore, relying on the conflict parties, the context of the conflict, the motivations behind the conflict, the consequences of the conflict, the duration of the conflict, the intensity of the conflict and absence or presence of violence in the conflict, among others, Ohana and Lyamouri-Bajja (2012, p. 57) attempt a classification of conflicts. The figure below encapsulates the classification of conflict for a broader horizon on the concept of conflict.

Alternative dispute resolution (ADR) refers to mechanisms for resolving conflicts/ disputes, other than the court or litigation processes/mechanisms. It refers to conflict resolution mechanisms done outside of the court. Often times, ADR are not in accordance with formal laws in society, hence, the term 'alternative'. Smith (1998) avers that ADR emerged owing to the often-cumbersome nature of the formal court processes and litigations. Hence, he avers that ADR are quicker and less cumbersome methods of conflict resolution. ADR could refer to any process or procedure or mechanism for conflict resolution, other than an adjudication by a judge in the court of law (Rozdeiczer \& Campa, 2006; Mnookin, 1998). ADR is "a general term used to define a set of 


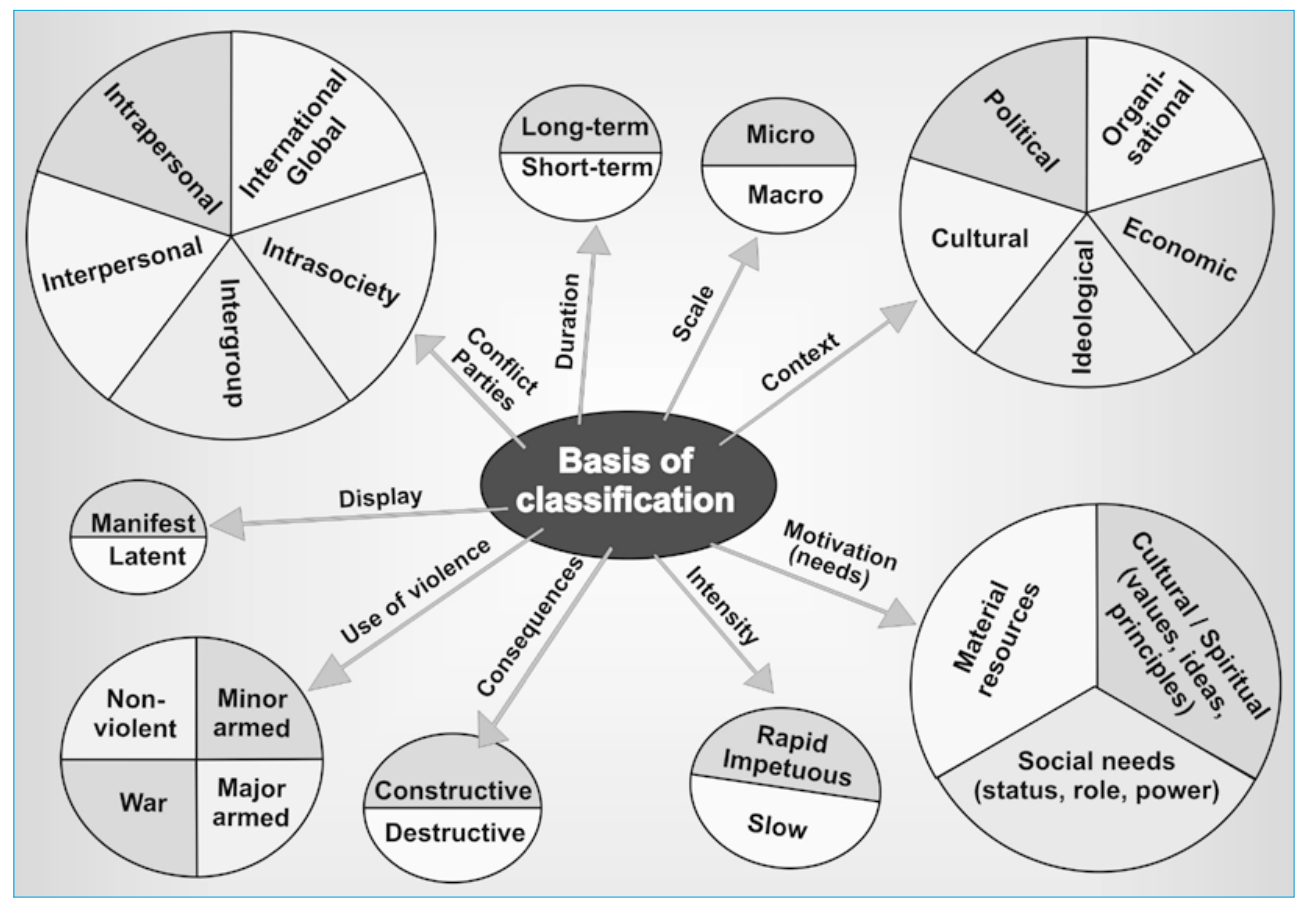

Figure 1: Classification of Conflicts

Source: Ohana and Lyamouri-Bajja (2012, p. 57)

approaches and techniques aimed at resolving disputes in a non-confrontational way" (Shamir, 2003, p. 2). It often involves third-party neutrals who are involved in facilitating the conflict resolution between or among parties (Kovach, 1994). This implies that the alternative dispute resolution usually, but not always, has third-party mediators who come in to resolve the conflict.

ADR methods have been categorized into two broad categories by Carver and Vondra (1994). The first category is the arbitration method under which parties involve in conflict agree to argue and settle their grievances before third party who then makes a binding decision on all. While the second category of ADR is negotiation; which may take the form of mediation, conciliation, etc. (Kauffman, 1992; Mckay, 1985). Overman (1992, p. 44) avers that the most common aspects of ADR are the arbitration and mediation methods. It is pertinent to note that ADR does not substitute the formal courts, rather, it only provides an alternative to it. It is "a range of procedures that serve as alternative to litigation through the courts for the resolution of disputes, usually involving the intercession and assistance of a neutral and impartial third party" (Brown \& Marriot, 2012, p. 12). 


\section{Post-conflict Societies in Transition - The case of Liberia}

For every society that has gone through conflict and achieved a measure of peace and stability, a number of measures must have been taken and implemented. In short, the time following crisis and conflicts are called post-conflict period. Therefore, preventing the re-occurrence of conflict(s) makes a society post-conflict society with the possibility of recurrence. The immediate aftermath of conflicts is seen as a period of transition in post-conflict societies. Missteps during this period, through lack of trust among the combatants, unfavourable background conditions or lack of clear-cut delineation of boundaries in terms of agreements among parties to the conflict can reignite or precipitate another round of crisis and/or intensify the previous conflict. While three reasons have been adduced as determinant of whether post-conflict societies in transition will fall back to conflicts, viz unfavourable internal conditions and contradictions (e.g. low income, resource dependency, conflict in the neighbourhood and the nature/character of the previous conflict); level of international support (ECOWAS, AU, UN, etc.) and the existence of frameworks to strengthen and support societal conflict transformation (SCT) platforms through ARD techniques (Afolabi \& Idowu, 2018; Fiedler \& Mroß, 2017; Sandu, 2013a). The existence and management of these conditions and frameworks often determine the sustainability of transition to peace of post-conflict societies.

For Liberia, the conflicts had their roots in the three conditions mentioned above. While unfavourable internal conditions and contradictions spurred and drove the violent conflicts, the level of international support at the initial stage was low, contributing to the intensity and longevity of the conflicts. The non-existence of frameworks to strengthen and support societal conflict transformation (SCT) platforms was also a factor in the conflicts. Remarkably, the elimination of unfavourable internal conditions and contradictions, or at least the minimization of the contradictions, increased level of regional, continental and international support and the development of frameworks to strengthen and support societal conflict transformation (SCT) platforms coupled with indigenous ARD mechanisms have helped solidify the peace process in post-conflict Liberia (Fiedler, Mroß, \& Grävingholt, 2016; Afolabi, 2015; Sandu, 2013b). We will now examine the ARD techniques used in Liberia to achieve peace.

\section{ADR Techniques in Liberia: A Critical Discourse}

From the historicity of conflicts in Liberia, there were three (land, woman and cattle money) primarily identified causes of conflicts in the setting of the indigenous people prior to the coming of modernity. The post-violence Liberia which was fragile, where societal tensions were very high, and the justice system was in dysfunction, there was the need for alternative dispute resolution. For as argued by Uwazie (2011), in such a post-violence society, where conflicts are not quickly attended to and treated with urgency, there are tendencies that such conflicts between/among individuals and groups 
have the capacity to degenerate into broader conflict, capable of throwing the country into yet another turmoil. One of the challenges towards peacebuilding in post-violence Liberia was one of lack of trust on the part of citizens towards the justice system. Hence, Flamoku and Reeves (2010) aver that it was indeed difficult to get Liberians to trust the judicial system in post-conflict Liberia, as such, the preference for ADR. Despite various reforms in Liberia's judicial system, the effect has not been widely felt by Liberians. This explains the prevalence of the ADR mechanisms in post-violence Liberia. A 2009 survey in Liberia reveals that only 3 percent of disputes were taken to formal courts, while a whopping over 40 percent disputes were resolved using ADR, and the others were cases wherein citizens took laws into their hands (Uwazie, 2011).

Whenever there are disputes, some alternative dispute resolution (ADR) mechanisms were used to ensure peaceful settlement. Any of the ADR mechanisms discussed in this section could be used, depending on the nature of the dispute or conflict and severity of the offence. As ADR mechanism in Liberia, mediation and negotiation were parts of the most prominent in the country (Afolabi \& Idowu, 2018). This section thus, takes a critical discourse on the various ADR in forms of negotiation and mediation adopted in post-violence Liberia.

\section{a. Town Hall}

The Town Hall method is used, when family head failed to resolve an issue arising from within the family. In its procedures, it very resembles with the divano and Kris Romani of the Roma community (Sandu, 2018). That is to say, two brothers or sisters or a sister and a brother or a husband and wife, and so on have a quarrel that their parents cannot handle, hence, it is brought before the family head. When the head of that family also fails to resolve the issue, then it is lifted to the head of the men or women groups, or the chief council (Galvanek, 2016). It is at this level, that a town hall meeting is held involving the disputed parties. There are always open hearings and cross-examinations that take into account the customary practices and procedures. Age, the status of the disputed persons, past involvement in previous conflicts, etc. are the parameters used to establish guilt. Penalties are paid by the party found guilty. Such penalties could include but are not limited to open apologies for days around the town at early morning or late evening. With the wrongdoer saying, for example; "I have offended Mr James by stealing his yams and do hereby apologize and ask for his forgiveness, so I am asking the town to join me in my pledge for mercy from him". In most instances, no fine is imposed.

The town hall meeting is usually run by traditional elders and could also be applied to disputes between and among communities. For instance, Flamoku and Reeves (2010) provide the example of the outbreak of violent conflict in Voinjama, Lofa County in February 2010 between youths of Lorme and Mandingo ethnicity, wherein the elders, via the town hall setting, resolved the conflict. Furthermore, in Bong County in December 
2010, the town hall ADR mechanism was also adopted wherein an elder resolved a 50year old land dispute between the Zaye, Queekon and Tonnie communities (Flamoku \& Reeves, 2010). These disputes resolved were capable of degenerating into full blown conflicts, but for the timely intervention of the elders' council via the town hall ADR system in Liberia.

In the town hall, disputes are resolved by chiefs, elders or spiritual leaders, using widely accepted cultural paradigms. Galvanek (2016) refers to the town hall ADR in Liberia as a system of indigenous court. When it comes to conflict resolution in Liberia, the indigenous people respect and listen to their chiefs and elders, hence, they are often the custodians of the town hall ADR mechanism. Currently, the chiefs who preside over the town hall meetings are positioned within the executive branch of government, under the Ministry of Internal Affairs; and they are often, elected by their own people (Galvanek, 2016). However, there has not been any election for the chiefs since 2006, but they are now being appointed mostly based on nepotism, cronyism or special favours (United Nations Mission in Liberia [UNMIL], 2011). Nevertheless, Isser, Lubkemann and Saah (2009, p. 25) argue that the above development has not in any way, affected the legitimacy of the council of chiefs who preside over town hall meetings.

In the town hall meetings presided over by chiefs and/or elders, the common method often used to achieve reconciliation and harmony is by addressing the root cause(s) of the dispute in the first place. The importance of addressing the root cause(s) of disputes during conflict resolution has been stressed - it ensures that future occurrences are prevented, rather than just dealing with the features of the present conflict (Afolabi \& Idowu, 2018). This practice of addressing the root cause of disputes in Liberia has been referred to as "searching for the truth, identifying the underlying issues and social factors that inform the disputes" (Isser, et al., 2009, p. 26). Galvanek (2016) explains the process of doing this thus: "...through story telling: recalling the history of the families of the disputes, how and when they migrated to the current place and how they have been friends, and in the case of land disputes, explaining the history of the land" (p. 19). Furthermore, it is important that the chiefs/elders, outside the town hall meeting proceedings, visit the conflict scene or where the conflicting parties reside (Galvanek, 2016). This is often with the belief that one cannot resolve a dispute from afar without visiting the scene of such conflict/dispute. One major sign to demonstrate that conflict has been resolved is by requiring the conflicting parties to bring food, come to the town hall, sit together and eat and dance to show harmony and forgiveness.

The town hall meeting ADR mechanism has been consistently chosen over the formal court system because it is less costly and does not often involve the bribes and kickbacks in the formal courts. Nevertheless, Galvanek (2016) opines that in Liberia, the community often meets the needs of these chiefs/elders who preside over town hall meetings. This, they do by tending their farms, bringing food to them and sometimes 
offering significant financial gifts to the chiefs/elders. However, these raise questions about the ability of the chiefs/elders to remain unbiased amidst these numerous favours. It also somewhat suggests paying the costs and kickbacks involved in the formal court system in disguise. Today, there has been transformation in the role of chiefs and elders. The traditional chiefs and elders have now been officially recognized by the Liberian government and has brought them under the aegis of National Council of Chiefs and Elders, to bridge the gap between government and the people.

\section{b. Women Leaders}

When it comes to the issues of peace, which conflict resolution is a significant part, women are central actors and 'right leaders' (Women's Organization, 2008). At the lowest level in Liberia, the women leaders' ADR mechanism is used when two ladies (either women or girls) quarrel and failed to resolve issue arising from such quarrels among themselves. Such disputes could include two ladies fighting over plot of land at the farming site, fighting over a gentleman, a lady beating up her friend's child and so on. Often times, the parties involved cannot handle the dispute among themselves, hence, it is brought before the woman leader. Then it is lifted to the head of the women groups, or the chief women council. It is at this level, that women meeting is held with the disputing parties in attendance. There are always opened hearings and cross-examinations that take into account the customary.

At a larger scale, the role of women and women leaders in conflict/dispute resolution in post-violence Liberia cannot be overemphasised. Galvanek and Planta (2017) observe that women leaders are accorded much respect in Liberia and they play a significant role in conflict resolution. Each community in Liberia has a woman leader who is active and influential in the community and continue to play a role in dispute resolution among her immediate populace. Women's role in peacebuilding in Liberia cuts across the local, national and international levels (Action Aid, Institute of Development Studies \& Womankind Worldwide, 2014). This role has been severally demonstrated both during and post-conflict periods in Liberia. Women's right organizations and movements have often demanded and mounted pressures on their leaders to comply with, implement and maintain peace accords in the country. Also, during the early years of the war, a national women's coalition group- 'concerned women of Liberia' built peace process by making direct contact with women held in territories by warring factions, usually via the instrumentalities of mediation and negotiation (African Women \& Peace Support Group, 1998, p.4).

The formation and existence of women groups such as the Mano River Union Women for Peace Network (MARWOPNET) and the Liberian Women's Initiative (LWI) (Afolabi \& Idowu, 2018; Badmus, 2009) were also platforms via which the ADR mechanism of women leaders came into play in Liberia. As Moran and Pitcher (2004) observe, the 
MARWOPNET played a significant role in bringing the Mano River presidents back to negotiations in September 2001 and the group was also a signatory to the Liberian Pace Accord in 2003. Furthermore, the LWI also played a role in attempts to frustrate the UN-sponsored peace accords because they saw the process as one which will further fuel the Liberian crisis (Action Aid, et al., 2014). Another women group - the Women in Peacebuilding Network (WIPNET) also launched a 'Women of Liberia Mass Action for Peace' campaign in 2003, "focusing on the cessation of hostilities between the warring parties; and lobbied at governmental and UN levels (Action Aid, et al., 2014, p. 3).

At the local level, the women/women leader ADR mechanism has also been effective in Liberia. Women in local rural areas use their positions within local institutions to rebuild, rehabilitate, reconstruct and reconcile war-torn communities. Moran and Pitcher (2004) provide an example of the Sande society in North-Western Liberia, where women leaders provide guidance for young girls who have lost their families. They also cite the example of the South-Eastern Liberia, where women leaders have been actively involved in the rehabilitation and reintegration of young male ex-combatants in their immediate communities. At the individual level, prominent women leaders, like Reffel Victoria, had played a significant role to secure the surrendering of Charles Tylor, the leader of the National Patriotic Front of Liberia (NPFL), a revolutionary force linked with major crises in Liberia. According to Badmus (2009), Reffel's diplomatic skills was key to convince the 1995 Extraordinary Summit of ECOWAS on Liberia of her boss' (Taylor) decision and willingness to negotiate peace. Reffel's diplomatic skill at the Summit eventually ensured that Taylor surrendered and apologized to Liberians for war crimes committed by the NPFL (Nigerian Tribune, 6 June, 1995, as cited in Annig, 1998, p.10).

In explaining their role in peace process in Liberia, Annie Saydee reveals "we talked to them [leaders of warring factions]. They are children to us and we wanted this fighting to stop. We, the women, bear that pain. So, we begged them - Kromah, Boley, Taylor at different times" (as cited in African Women and Peace Support Group, 2004, p.13). Another prominent display of the women ADR mechanism in conflict resolution played out when the women organization Women in Liberia Liberty (WILL) "initiated food aid and sensitization programmes that helped tremendously in alleviating the sufferings of war victims" (Badmus, 2009, p. 828). Also, during the war, another women group, the Women in Peacebuilding Network (WIPNET) mobilized and organized protests against the NPFL government and also organised prayer and fasting programmes to put an end to the conflict in Liberia. All of these women's action contributed in no small measure to the resolution of conflicts in Liberia and the restoration of peace in the country.

The role of women and women leaders in Liberia's peace process and national affairs is evident in the country's records in women leadership. Liberia holds the record of the first female president elected in 2005, the first female president of an African national university and the first female Head of State (Action Aid, et al., 2014). 


\section{c. Cultural Fraternity (Sandi/Poro)}

The cultural fraternity (Sandi/Poro) ADR method is used between members of the fraternities but also used to ensure public ordinance within communities. If a person uses a language that is considered as taboo or committed an act against the community, or the population, the fraternity comes in to settle any such disputes (Sites of Liberia, 2009). That is to say, a person commits a crime that is above the jurisdiction, like broken the laws of the community, killed a person or any such. It is at this level that a fraternity is being used involving the disputed parties or persons. There are almost, always no open hearings and cross-examinations that take into account the fraternity procedures. This is always concluded with fine of various types (goats, cows, based on the nature of the offence). This operates more often at the local level within the local communities. Disputes that are not resolvable by the cultural fraternity are taken to the elders/chiefs under the town hall meetings. The cultural fraternity is mostly made up of members who are the custodians of the cultures of the various local communities; and as such, it often deals majorly with cultural disputes.

\section{d. Clan-to-Clan}

This is somewhat similar to the elders/chiefs and the town hall ADR mechanism in Liberia. The clan-to-clan method is used when there are issues arising from between clans. That is to say, two or more clans are in a dispute that they cannot handle, hence, it is brought before the clan council. Then, it is lifted to the head of the clan council. It is at this level that the clan council meeting is held involving the disputed clans. The clan council is often made up of hierarchy of chiefs before whom the disputes are presented and the conflicts are resolved via a mixture of mediation and arbitration (Galvanek \& Planta, 2017). The procedure to be adopted, whether it is mediation, arbitration or both varies, mostly based on the individual chiefs involved in the cases of disputes.

The decision from clan-to-clan dispute resolution are not rushed but are taken at a slower pace in order to give room to the different clans involved in the conflict to reflect and also to reach consensus (Galvanek \& Planta, 2017). The single objective of the clan-to-clan ADR mechanism of dispute resolution mechanism in Liberia is to achieve social reconciliation and also to restore harmony between and among conflicting clans. This will further give room for peaceful coexistence among members of the community. Issues that go beyond the management or settlement within the clans are referred to the clan council for the resolution of such conflicts. The clan council is usually headed by a high-ranking chief who oversees a clan meeting over the resolution of a given clanto-clan dispute. The clan-to-clan ADR mechanism of dispute resolution thus ensures that clan-to-clan disputes do not degenerate into community dispute, which has the potential of graduating into full-blown civil wars. There are always open hearings and cross-examinations that take into account the customary laws. This is always concluded with fine of various types. 


\section{e. Conflict Resolution by Ordeal (Sassy Wood)}

Ordeal is the most common means or mechanism by which the settlement of disputes among the particularly rural population. Also known as 'Sassy wood', it is a controversial dispute resolution mechanism in Liberia. This practice is basically permanent among the indigenous settlements within the social-political and social-economic frontier of the nation's geography. Those who practice this are licensed by the government via the local or municipal authorities. They are said to be able to determine any wrong doer within the society, ranging from stolen properties, witchcraft activities, adulteries and any such offence against humanity and society (Ntuli, 2018). This system of dispute resolution, according to Ntuli (2018), Flamoku and Reeves (2010) and Galvanek and Planta (2017) has to do with an adjudication process which is based on the superstition that the judgement of guilt could be found in the hands of ancestral spirits. This ordeal ADR system is reserved for serious crimes and offences, such as rape, murder, theft and witchcraft, among others. Some of the approaches of the ordeal mechanism of dispute resolution are thought to be harmful (Flamoku \& Reeves, 2010) and backwards (Galvanek \& Plante, 2017) too.

One method often adopted by the ordeal system of dispute resolution is one in which victims are meant to take normally harmful substances, such as poisons, or having a red-hot cutlass placed on his/her legs. When the accused is guilty, he/she will definitely be hurt by any of these and if the accused is innocent, nothing will happen to him/her (Chereji \& Wratto, 2013). Isser, et al. (2009, p.58) assert that the "supernatural power of the ritual will protect the innocent from harm". What this implies is that the guilty of alleged crimes will usually be hurt by either the poisonous foods or the red-hot cutlass, whereas, the innocent will not suffer any hurt under this mechanism. Another less harmful method adopted in the ordeal dispute resolution mechanism is by giving the accused person foods that are ordinarily not harmful or poisonous to consume. While the healthy non-poisonous food will hurt a guilty person, it will, nonetheless, not hurt an innocent person (Galvanek \& Planta, 2017). Ntuli (2018) provides yet another strand of the dispute resolution by the bitter drink method. Here, the accused is presented with a bitter drink made from a local indigenous bitter plant, to consume. Regurgitating the bitter drink demonstrates innocence, whereas, where an accused fails to regurgitate the bitter drink, then, he is found guilty.

Once found guilty under the ordeal mechanism, such a person is publicly shamed and made to repent of his crimes, while also making a public apology, plus a paid compensation to his accuser. As a small parenthesis, shame is the central concept in any indigenous conflict resolution mechanism and it is understood as an efficient mechanism to control the behaviour of the individuals. This done, the guilty will then be reunited and reintegrated back into the community (Chereji \& Sandu, 2018). Ntuli (2018) avers that in the case of witchcraft or murder, the offender could be punished to the extent of 
being banished from the community. The major purpose of the ordeal dispute resolution mechanism is to keep crime as low at the barest minimum and also to encourage people to be truthful when a crime has been committed or when a dispute is being resolved (Galvanek \& Planta, 2017, p. 33). However, given the very harmful nature of most strands of the ordeal method and the belief that it undermines human rights, the method has been banned by the Liberian government (Ntuli, 2018; Galvanek \& Planta, 2017). This ban has however not gone down well with most Liberians, especially traditional leaders. This is so, as the traditional leaders and their communities believe that the ban on the ordeal ADR dispute resolution mechanism has led to a significant decrease in the "effectiveness of the customary system, as it has removed a method for them to ascertain the truth in particularly difficult cases" (Isser, et al., 2009, p. 64). Notwithstanding this government ban, however, Ntuli (2018) avers that "it continues to be used and trusted by many" (p. 44).

\section{f. Palaver Hut and Kinship of Pleasantry}

These ADR mechanisms have served as forums where perpetrators, victims and survivors meet and confess. On the one hand, perpetrators confess their war crimes and, on the other hand, war survivors forgive them or subject them to go through community punishment as the case may be (Afolabi \& Idowu, 2018; Kurz, 2010). As the name implies, the palaver hut is usually held in a round hut, where, under the leadership of community elders, the villagers gather to resolve disputes and mediate reconciliation (Ntuli, 2018). The palaver hut is an environment held with high esteem and believed to be sacrosanct. This is due to the superstitious belief that ancestral spirits are also in attendance and, as such, people do not leave the hut until disputes are fully resolved (Ntuli, 2018). For Pajabo (2008), the palaver hut can be applied in all kinds of disputes and its major aim is to get admission of guilt and apology from the offender and forgiveness from the victim. At the acceptance of the apology, the offender owes certain compensation to the victim, after which they (offender and victim) share a plate of food as a sign of sincere forgiveness (Danso, 2016). Danso (2016) further posits that the spirits are usually invoked during the process, so as to get all the parties to the dispute to be truthful, else, they will face the wrath of the spirits.

According to Naine (2005), the kinship of pleasantry creates a forum for a kind of friendship formed across cultural ties, usually based on humour and mockery. This should normally and usually contribute to the disruption of mounting pressures which are capable of midwiving full-blown crisis.

\section{g. Sharing the Kola Nut}

This ADR method in Liberia is usually based on forgiveness and is built on the slogan of "let bygones be bygones" (Pajabo, 2008). It is a system that also has to do with elders' investigation of a conflicting issue brought before them. In this method, when the ac- 
cused is found guilty, he/she is asked to ask for forgiveness from his accuser/or victim. Ntuli (2018) observes that as a sign to show that forgiveness has been obtained, the accused offers kola nut to the victim; if the victim throws the kola nut away, it means he is not ready to forgive, but if he eats half of the kola nut and offers the other half to the accused, then he has forgiven him of his crime. The breaking and sharing of kola nuts between the accused and the victim thus symbolizes forgiveness and reconciliation in this mechanism of dispute resolution in Liberia.

\section{Problems of ADR in Liberia: Examining Limitations and Lessons Learned}

There is no gainsaying the fact that the various ADR mechanisms which have been adopted in Liberia has been productive in terms of dispute resolution. Albeit, this has not also been without some problems and/or limitations. For instance, no doubt that women have played a prominent role in peacebuilding in Liberia, however, the potentials of that mechanism still remain to be fully tapped and exploited, owing largely to what Badmus (2009) refers to as the 'socio-cultural practices of patriarchy'. The fact that men are still continuously being placed above women in the society in most parts of Africa, Liberia inclusive, has ensured that the women have not fully played a role in dispute resolution. This is true to the extent that most of these issues are consistently referred to the elders, who are mostly men in the society. Women's opinions and views are scarcely sought when there are issues of dispute in the society (Ekiyor, n.d.). One obvious practice of patriarchy in Liberia, for instance, is the prioritizing of the male child education to that of their female counterpart. This was reaffirmed as Angela Kearney, the UNICEF Liberian representative asserts: "we continue to remain in a situation where girls remain at a distinct disadvantage when it comes to enjoying their right to quality basic education. Consider these facts: the present ratio of girls to boys at the primary school level in Liberia is 40\% to 59\%" (UNICEF, Online, April 17, 2006). The continuous relegation of women to the back seat has continued to pose a limitation to the extent to which women can be fully utilized as an ADR mechanism in Liberia.

Closely linked to the above is the exclusion of youths from conflict resolution processes in Liberia. In Liberia, young and unmarried men/women are mostly excluded from decision-making processes, including those related to dispute resolution (Galvanek \& Planta, 2017). Galvanek and Planta (2017) further aver that the exclusion of youths, arguably, was one of the major factors which led to the Liberian civil wars, as warlords consistently exploited the frustration, exclusion and grievances of youths. This corroborates with Carl's (2003) position that some traditional conflict resolution mechanisms have the potentials to "reinforce undemocratic patron-client relationships and may have contributed to the conflict" (p. 4). Hence, rural youths in Liberia felt "ill-treated with regard to land and marriage prospects by the customary sector" (Unruh, 2007, p. 7), a situation believed to have led to resentment and also contributed to the war. 
Furthermore, the tendencies for some of the ADR mechanisms to abuse human rights is very much present. For instance, the conflict resolution by ordeal has been labelled as harmful and backwards (Galvanek \& Planta, 2017). This is justified, given that some of the ordeal practices, as revealed in previous section, are very dangerous and indeed fatal and do not also conform with the ethics of punishment for crimes or offences, thereby posing a threat to human rights. For example, the ordeal method which requires people to drink from harmful substances, such as poison or have red-hot cutlass placed on his/ her leg (Isser, et al., 2009, p.58) are obviously an abuse on human rights. Uwazie (2011) also notes the possibility of some ADR mechanisms/practices being at odds with the modern and formal mechanisms, hence, could be very controversial. The ADR mechanisms in Liberia have also been significantly weakened by the wars. Circumstances such as "lack of resources and unclear mandates" have undermined, to a large extent, the ability of Liberian chiefs and elders to resolve conflicts (Uwazie, 2011, p. 45).

Generally, giving it an African perspective, Uwazie (2011) observes that ADR programmes face four key challenges in Africa; viz: "inadequate political support, human resources, legal foundations and sustainable finances" (p. 5). This situation is not different in Liberia, where the government is often slow to understand and recognize the usefulness/need of ADR and, as such, they are often left in the hands or the third-party donors.

\section{Retooling the ADR Mechanism as a Peace-building Technique - Exploring Possibilities}

Because of the significant role ADR mechanisms have played in conflict resolution in Liberia and given the numerous challenges the ADR face, there is enough room for improving ADR in Liberia. This will ensure that the ADR mechanism is further and better utilized for dispute resolution in the country. To achieve this, steps/actions must be put in place to address the critical limitations/challenges which ADR encounters here. Since the role of women in ADR cannot be overemphasized, one critical step towards improving ADR in Liberia, therefore, would be the need to encourage women participation in conflict resolution processes (Badmus, 2009). This can be achieved by increasing the acceptance and incorporation of the views and opinions of women into peace negotiations. Women must also be given equal rights as their male counterparts, in terms of access to formal education. By educating the women, they are empowered which has the potentials of getting more women involved in dispute resolution. There is also the need to involve youths more in the ADR methods in Liberia. There is also the urgent need to completely modify or jettison those ADR mechanisms which tend towards barbarism and abuse of human rights.

Uwazie (2011) generally highlights, some important steps towards improving ADR in Africa. he argues that these steps are also useful to improve the ADR mechanism in 
Liberia. Uwazie's steps include:

- Enacting robust ADR legislation: This is believed would improve the status of ADR, build public confidence and increase ADR's utilization;

- Investing in a broad capacity building: This will further improve the country's litigation and prevention capacity;

- Creating appropriate incentives for stakeholders: This will make clearer the benefits and contributions of ADR mechanisms to legal professionals, which will further improve the scope and use of ADR mechanism;

- Measuring progress: This will maximize the efficiencies and complementarities of ADR in the country; and

- Targeting youths early: This will not only improve the ADR mechanism, but will also engage the youths, thus, reducing youth restiveness which is capable of degenerating into civil wars (p. 36).

\section{Conclusion: Immediate needs, future projections}

The prevalence of violence and conflicts in Africa attracts the need for measures that stem and address, in a mediate manner, the recourse to conflicts as well as interrogate the alternative dispute resolution mechanisms that can be used to achieve peace, especially in post-conflict societies. This approach has two-way benefits, providing an understanding of the ADR techniques and how these can be used to in post-conflict societies, especially in Africa. Liberia, as unit of analysis, has had several recurrences of violence and conflicts calling for the need for ADR. The paper identified unfavourable internal conditions and contradictions (e.g. low income, resource dependency and conflict in the neighbourhood and the nature/character of the previous conflict); level of international support (ECOWAS, AU, UN, etc.) and the existence of frameworks to strengthen and support societal conflict transformation (SCT) platforms as issues that could shape and determine re-occurrence of violence and conflicts. The adoption of indigenous ADR techniques, including the ones discussed in this paper, it is believed, would go a long way to help put an end to conflicts and help post-conflict societies in Africa achieve peace.

\section{References:}

1. Action Aid, Institute of Development Studies, \& Womankind Worldwide (2014). From the Ground up, Country Focus: Women's Roles in Local Peacebuilding in Liberia. Action Aid, IDS and Womankind Worldwide Publications.

2. Afolabi, O. S. (2015). Ethnic Conflict in Multinational West Africa. Encyclopaedia of Modern Ethnic Conflict. Santa Barbara: ABC-CLIO/Greenwood Publishers.

3. Afolabi, O. S., \& Idowu, H. A. (2018). Mano River Basin: An Evaluation of Negotiation and Mediation Techniques. Conflict Studies Quarterly, 25, 3-19.

4. African Women and Peace Support Group (1998). African Women and Peace: Liberia Women's Initiative and Actions. Unpublished Proposals. 
5. African Women and Peace Support Group (2004). Liberian Women Peacemakers. Asmara: Africa World Press.

6. Annig, E. K. (1998). Women and Civil Conflict: Liberia and Sierra Leone. African Journal of International Affairs, 1(2), 45-58.

7. Badmus, I. A. (2009). Explaining Women's Roles in the West African Tragic Triplet: Sierra Leone, Liberia and Cote D'Ivoire in Comparative Perspective. Journal of Alternative Perspectives in the Social Sciences, 1(3), 808-839.

8. Bakken, I. V., \& Rustad, S. A. (2018). Conflict Trends in Africa, 1989-2017. Conflict Trends, 6. Oslo: Peace Research Institute (PRIO).

9. Brown, H. J., \& Marriot, A. L. (2012). ADR Principles and Practice ( $3^{\text {rd }}$ Ed.). London: Sweet and Maxwell.

10. Carl, A. (2003). Supporting Local Capacities for Handling Violent Conflict: A Role for International NGOs? Occasional Paper. London: Conciliation Resources.

11. Carver, T. B., \& Vondra, A. A. (1994). Alternative Dispute Resolution: Why it doesn't work and why it does. Harvard Business Review, 72, 120-130.

12. Chereji, C., \& Wratto, K. C. (2013). West Africa: A Comparative Study of Traditional Conflict Resolution Methods in Liberia and Ghana. Conflict Studies Quarterly, 5, 3-18.

13. Chereji, C., \& Sandu, C. (2018). Romania: The Kris Procedures. A Brief Incursion in the Roma Community-Based Dispute Management Mechanisms. Conflict Studies Quarterly, 24, 3-11.

14. Danso, K. (2016). Mending Broken Relations after Civil War: The 'Palava Hut' and the Prospects for Lasting Peace in Liberia. Accra: Kofi Annan International Peace Keeping Training Centre.

15. Diez, T., Stetter, S., \& Albert, M. (2006). The European Union and Border Conflicts: The Transformative Power of Integration. International Organization, 60(3), 563-593.

16. Dokubo, C., \& Oluwadare, A. J. (2011). Nigeria's Role in Conflict Resolution: A New Paradigm. Journal of Alternative Perspectives in Social Sciences, 3(3), 551-580.

17. Donohue, W. A., \& Kolt, R. (1992). Managing Inter-personal Conflict. Thousand Oaks: Sage Publication.

18. Ekiyor, T. (n.d.). Female Combatants in West Africa: Progress or Regress? Accra: WANEP.

19. Engel, A., \& Korf, B. (2005). Negotiation and Mediation Techniques for Natural Resource Management. Rome: Food and Agriculture Organization of the United Nations (FAO).

20. Fiedler, C., Mroß, M., \& Grävingholt, J. (2016). Building Peace after War: The knowns and unknowns of External Support to Post-conflict Societies. Briefing Paper, 11/2016. Bonn: German Development Institute / Deutsches Institut für Entwicklungspolitik (DIE).

21. Fiedler, C., \& Mroß, K. (2017). Post-Conflict Societies: Chances for Peace and Types of International Support. Bonn: German Development Institute / Deutsches Institut für Entwicklungspolitik (DIE).

22. Fisher, S. A., Abdi, D. I., Smith, R., Williams, S., \& Williams, S. (2000). Working with Conflict: Skills and strategies for Action. London: Zed Books. 
23. Flamoku, P., \& Reeves, C. L. (2010). Formal and Informal Justice in Liberia. Accord, 23. Conciliation Resources. Retrieved from https://www.c-r.org/accord-article/formaland-informal-justice-liberia.

24. Galvanek, J. B. (2016). Pragmatism and Mistrust: The Interaction of Dispute Resolution Mechanisms in Liberia. Berlin: Berghof Foundation.

25. Galvanek, J. B., \& Planta, K. (2017). Peaceful Coexistence? 'Traditional and Non-traditional' Conflict Resolution Mechanisms. Berlin: Berghof Foundation Operations.

26. Isser, D. H., Lubkemann, S. C., \& Saah, N. (2009). Looking for Justice: Liberian Experiences with and Perceptions of Local Justice Options. Washington D.C.: United States Institute of Peace.

27. Jack, E. C. (2014). The African Union's Involvement in Conflict Resolution in Some ECOWAS Countries (Unpublished MA Thesis). Brandeis University, Waltham, USA.

28. Kauffman, N. (1992). Expedited Arbitration and Other Innovations in Alternative Dispute Resolution. Labour Law Journal, 43, 382-387.

29. Kovach, K. (1994). Mediation: Principles and Practice. St. Paul: West Publishing Co.

30. Kurz, C. P. (2010). Cumulative Impact Case Study: The Cumulative Impact of Peacebuilding in Liberia. Cambridge: Collaborative Learning Project, CDA.

31. McKay, R. (1985). The many Uses of Alternative Dispute Resolution. The Arbitration Journal, 40(3), 12-16.

32. Mnookin, R. H. (1998). Alternative Dispute Resolution. Discussion Paper Series, paper 232. Cambridge: Harvard Law School, John M. Olin Center for Law, Economics and Business.

33. Moran, M. H., \& Pitcher, M. A. (2004). The 'Basket Case' and the 'Poster Child': Explaining the End of Civil Conflicts in Liberia and Mozambique. Third World Quarterly, 25(3), 501-519.

34. Naine, D. T. (2005). Kinship of Pleasantry: Historical Origin, Preventive and Regulatory Role in West Africa. Initiative on Capitalizing Endogenous Capacities for Conflict Prevention and Governance, Compilation of Working Documents. Conakry: Club du Sahel et de L'Afrique de L'Ouest.

35. Ntuli, N. (2018). Africa: Alternative Dispute Resolution in a Comparative Perspective. Conflict Studies Quarterly, 22, 36-61.

36. Ohana, Y., \& Lyamouri-Bajja, N. (2012). Nigeria's Role in Conflict Resolution: A New Paradigm. Journal of Alternative Perspectives in Social Sciences, 3(3), 551-580.

37. Oni-Ojo, E. E., \& Roland-Otaru, C. (2013). Alternative Dispute Resolution Strategies for Sustainable Development in Africa: Insights from Nigeria. Journal of Management and Entrepreneurial Development, 3(1), 37-54.

38. Overman, S. (1992). Resolve Dispute without Costly Suits. HR Magazine, 37, 44-45.

39. Pajabo, E. (2008). Traditional Justice Mechanisms: The Liberian Case. Stockholm: International Institute for Democracy and Electoral Assistance Publications.

40. Pia, E., \& Diez, T. (2007). Conflict and Human Rights: A Theoretical Framework. SHUR Working Paper Series, 1(07). Birmingham: University of Birmingham. 
41. Rozdeiczer, L., \& Campa, A. A. (2006). Alternative Dispute Resolution Manual- Implementing Commercial Mediation. Washington D.C.: The World Bank Group.

42. Quincy, W. (1971). The Escalation of International Conflicts. London: Noitre Dame Press.

43. Sandu, C. (2013a). Mediation. Measuring the success of mediation. Conflict Studies Quarterly, 2, 30-39.

44. Sandu, C. (2013b). Mediation. Building Trust. Conflict Studies Quarterly, 4, 57-69.

45. Sandu, C. (2018). Romania: Traditional Conflict Resolution Mechanisms Used by the Roma Communities. Conflict Studies Quarterly, 22, 95-108.

46. Shamir, Y. (2003). Alternative Dispute Resolution Approaches and their Application. Paris: UNESCO.

47. Sites of Liberia (2009). Simple Palaver Huts. Sites of Liberia. Retrieved from http:// www.sitesofliberia.wordpress.com/2009/08/08/a-simple-palaver-hut.

48. Smith, C. R. (1998). Mediation: The Process and the Issues. Kingston: IRC Press, Industrial Relations Centre, Queen's University.

49. Stagner, R. (1967). The Dimension of Human Conflict. Detroit: Wayne State University Press.

50. Thomas, K. W. (1976). Conflict and Conflict Management. In M. D. Dunnette (Ed.) Handbook of Industrial and Organizational psychology (pp. 889-935). Chicago: Rand McNally.

51. UNICEF (2006, April 17). Liberia to Launch Girl's education National Policy. UNICEF. Retrieved from http://www.unicef.org/media/media_33392.html.

52. United Nations Mission in Liberia (UNMIL) (2011). Case Progression: Paramount Chiefs and Tribal Governors' Courts Structure. Monrovia: UNMIL - Legal and Judicial System Support Division.

53. Unruh, J. D. (2007). Land Tenure. In Republic of Liberia Ministry of Agriculture, Comprehensive Assessment of the Agricultural Sector, Vol. 2.2, Sub-sector Reports, (pp. 6994). Gardnersville: Republic of Liberia Ministry of Agriculture.

54. Uwazie, E. E. (2011). Alternative Dispute Resolution in Africa: Preventing Conflict and Enhancing Stability. African Security Brief, 16, 1-6.

55. Wertheim, E. (n.d.). Negotiations and Resolving Conflicts: An Overview. Boston: College of Business Administration Northeastern University.

56. Women's Organization (2008, January 25). Women's Memorandum to the Mediation Team. Pambazuka News. Retrieved from https://www.pambazuka.org/gender-minorities/women\%E2\%80\%99s-memorandum-mediation-team 